book of reference on British birds, alike on the book-shelf of the student and in the library of the country gentleman, for many years to come.

\title{
Russian Central Asia. By Henry Lansdeld, D.D. In two volumes. 8vo. London, 1885.
}

ZooLogisTs will experience much satisfaction in finding in a work, the author of which does not claim to be a naturalist, unexpectedly a source of information which is all the more welcome as it refers to a part of the globe that claims our attention in an unusual degree. We sadly. missed in Dr. Lansdell's first work, 'Through Siberia, information as to the natural productions of that remote region, and could not help feeling that an opportunity had been lost. This is in some measure remedied in this new work on Russian Central Asia. It forms two large volumes, handsomely illustrated with seventy engravings and maps.

The bulk of the work is occupied by the author's record of his journey of 12,000 miles through Western Siberia to Kuldja, thence through the Kirghese steppes to Tashkend, Khokand, and Samarkand. Crossing into Bokhara he travelled to the Oxus, down which he floated 300 miles to Khiva, and then continued by a new route across the land of the Turkomans and north of Merv to Krasnovotsk. As province by province of Russian Central Asia are described, their several faunas and floras are shortly characterized; but the most important part of the information is contained in the appendices at the end of the second volume, which extend to about 150 pages of closely but clearly printed matter.

Concerning the famna of Russian Turkestan Dr. Lansdell, after pointing out that until within the last thirty years Turkestan was all but unknown to science, gives a brief account of the various naturalists who have proceeded there-amongst whom the first place is very properly given to Professor A. P. Fedchenko, whose work, written in Russian, is unfortunately a closed book to the majority of English naturalists.

Thanks to help which Dr. Lansdell has received, the introductions to the various portions of Fedchenko's collection are translated and supplemented by lists of the species, so that the English reader may obtain a good idea of the fauna and flora of the region traversed. Severtzoff's lists of mammals and birds had already been translated, and to these Dr. Lansdell adds those of reptiles and amphibians, giving here, as also with the mammals and birds, both the vertical and horizontal distribution.

We have next the monograph on Turkestan fishes by K. F. Kessler. In the account of the Mollusks the area is extended beyond Turkestan to the Altai, the Trans-Baikal, Afghanistan, Tibet, Cashmir, North-west Himalayas, and Yun-nan. Five pages are devoted to Arachnida, with 146 species, after which follow the Crustaceans and Coleoptera. At the end of this last order Dr. Lansdell 
gives a portion of Solsky's third part, which was not published at the time of that author's death.

The tables on Hymenoptera and Lepidoptera are particularly full, and to each species is added its distribution in other countries and its vertical distribution in Turkestan. M. Alpheraky, of Taganrog, has furnished Dr. Lansdell with a list of 377 species of Lepidoptera he captured in the Kuldja valley, giving the altitude at which each species was taken and the month of capture. The remaining lists contain Neuroptera, Orthoptera, and Vermes.

It should be added that these lists respectively have been rerised for the most part by their authors, or, rather, those of them who are living; and Madame Fedchenko, who edited so many of her husband's works after his lamented death, has also revised the tables in their English dress.

A separate appendix is devoted to the flora of Russian Turkestan, and comprises 1234 plants ; whilst a third consists of a most valuable bibliography of 700 publications on that region in English, French, German, Russian, and other languages.

Dr. Lansdell has been too successful a traveller to resistlong the temptation of invading other regions of the east. We understand that the last sheet of his work had hardly been passed through the press when he started again for Asia Minor; and we have no doubt that this new journey will contribute not only to our information, but also to our collections.

\section{Our Insect Enemies. By THEODORE Wood. Small 8vo. London :} Society for Promoting Christian Knowledge. 1885.

Mr. Wood has followed up his little book on 'Our Insect Allies,' which we noticed just a year ago, with a similar volume on injurious insects. The view of the real nature of the relations of insects, whether injurious or beneficial, to man, which we indicated as the guiding principle of the author in discussing these matters, is still further developed in his present work, in which he describes the structure and natural history of a select few of those insects whose existence acquires prominence by the mischief they cause to us. The little histories are told in a pleasant style, and in his two books the author has certainly furnished an excellent popular contribution to entomological literature, and one which may serve as a valuable guide in the first steps to a knowledge of the economy of the insect world. The principal mistake he has fallen into is his devoting nearly a quarter of his present volume to the natural history of the Aphides, a subject which, although most interesting to the entomologist, can hardly have its full importance realized by the beginner, while its occupying so much space has evideutly led to some other sections of the work being somewhat starved. The volume is illustrated with a good many woodeuts, mostly of pretty good quality. 


\section{$2 \mathrm{BHL}$ Biodiversity Heritage Library}

1885. "Russian Central Asia. By Henry Lansdell, D.D. In two volumes. 8 vo. London, 1885." The Annals and magazine of natural history; zoology, botany, and geology 16, 393-394. https://doi.org/10.1080/00222938509459899.

View This Item Online: https://www.biodiversitylibrary.org/item/94955

DOI: https://doi.org/10.1080/00222938509459899

Permalink: https://www.biodiversitylibrary.org/partpdf/68499

\section{Holding Institution}

Harvard University, Museum of Comparative Zoology, Ernst Mayr Library

\section{Sponsored by}

Harvard University, Museum of Comparative Zoology, Ernst Mayr Library

\section{Copyright \& Reuse}

Copyright Status: Public domain. The BHL considers that this work is no longer under copyright protection.

This document was created from content at the Biodiversity Heritage Library, the world's largest open access digital library for biodiversity literature and archives. Visit BHL at https://www.biodiversitylibrary.org. 